\title{
SUBMICROSCOPIC CHANGES OF SECRETORY CARDIOMYOCYTES UNDER THE EXPERIMENTAL HYPERGLYCEMIA IN RATS OF DIFFERENT AGE GROUPS
}

\author{
Submicroscopic changes of secretory cardiomyocytes \\ under the experimental hyperglycemia in rats of \\ different age groups
}

\author{
S. V. Trach Rosolovska, Z. M. Nebesna, Y. Y. Bodnar, \\ V. V. Kulbitska \\ I. Horbachevsky Ternopil National Medical University
}

e-mail: nebesna_zm@tdmu.edu.ua

Summary. Diabetes mellitus today is one of the most common diseases of humankind. One of the risk factors for heart disease in diabetes is chronic hyperglycemia, which causes cardiovascular disease and myocardial injury. Ultrastructural changes of endocrine cardiomyocytes of a heart in hyperglycemia in the experiment require more detailed study.

The aim of the study - to establish submicroscopic changes of atrial myoendocrine cardiomyocytes under the conditions of modeling of experimental hyperglycemia in rats of different age groups.

Materials and Methods. The study was performed on 24 outbreeding nonlinear adult male rats. Experimental hyperglycemia was simulated by a single intraperitoneal injection of streptozotocin (Sigma, USA). Animals were divided into two age groups: of pre-reproductive and reproductive age. For electron microscopic studies, sections 0.4-0.6 $\mu \mathrm{m}$ thick were made on an ultramicrotome, and were studied using an electron microscope PEM-125K.

Results. Submicroscopic studies of the right and left atrial appendages (auricles of the heart) of the studied groups of animals after one month of experimental persistent hyperglycemia showed changes in the structure of almost all organelles of endocrine cardiomyocytes. Changes in secretory cells of the right and left atrial appendages after two months of experimental persistent hyperglycemia showed an increase in destructive changes in the structural components of cells, which were more pronounced in the group of animals of pre-reproductive age. The diffuse collagenization of the stroma was a typical sign of ultrastructural changes in the atrial appendages after three months of experimental persistent hyperglycemia.

Conclusions. At experimental steady hyperglycemia at animals of different age groups stereotypical ultrastructural reorganization of secretory cardiomyocytes of right and left atrial appendages with development of compensatory-adaptive and destructive changes is noted. In the dynamics of the experiment there is an increase in destructive
Субмікроскопічні зміни секреторних кардіоміоцитів за умов експериментальної гіперглікемії у щурів різних вікових груп

С. В. Трач Росоловська, 3. М. Небесна, Я. Я. Боднар, В. В. Кульбіцька

Тернопільський національний медичний університет імені І. Я. Горбачевського МОЗ України

Резюме. Цукровий діабет на сьогодні є одним із найпоширеніших захворювань людства. Найважливішими оракторами ризику ураження серця при цукровому діабеті є хронічна гіперглікемія, що спричиняє розвиток серцево-судинної патології та сприяє ушкодженню міокарда. Ультраструктурні зміни ендокринних кардіоміоцитів серця при гіперклігемії в експерименті потребують більш детального вивчення.

Мета дослідження - встановити субмікроскопічні зміни передсердних міоендокринних кардіоміоцитів за умов моделювання експериментальної гіперглікемії у щурів різних вікових груп.

Матеріали і методи. Дослідження проведено на 24 нелінійних статевозрілих щурах-самцях. Експериментальну гіперглікемію моделювали шляхом одноразового внутрішньочеревного введення стрептозотоцину («Sigma», USA). Тварин розподіляли на дві вікові групи: щури дорепродуктивного віку та репродуктивного віку. Для електронно-мікроскопічних досліджень брали зрізи товщиною 0,4-0,6 мкм, виготовлені на ультрамікротомі, та вивчали за допомогою електронного мікроскопа ПЕМ-125К.

Результати. Субмікроскопічні дослідження правого $i$ лівого вушок серця дослідних груп тварин при одномісячній експериментальній стійкій гіперглікемії показали зміни в будові практично усіх органел ендокринних кардіоміоцитів. Зміни ендокринних кардіоміоцитів правого і лівого вушок серця при двомісячній експериментальній стійкій гіперглікемії показали наростання деструктивних змін складових компонентів клітин, які були більш виражені у групі тварин дорепродуктивного віку. Виявлена дифузна колагенізація строми була типовою ознакою ультраструктурних змін вушок серця при тримісячній експериментальній стійкій гіперглікемії.

Висновки. При експериментальній стійкій гіперглікемії у тварин різних вікових груп відмічається стереотипна ультраструктурна реорганізація секреторних кардіоміоцитів міокарда вушок серця з розвитком компенсаторно-пристосувальних і деструктивних змін. В динаміці експерименту спостерігається нарос- 
phenomena, the severity of which is higher in the group of rats of pre-reproductive age.

Key words: heart; myocardium; secretory cardiomyocytes; submicroscopic changes; hyperglycemia.

\section{INTRODUCTION}

Diabetes mellitus (DM) is currently one of the most common diseases of humankind, leading to disability and mortality in many countries around the world. According to the WHO, the number of patients with diabetes is growing every year and currently stands at more than 180 million people, according to experts in the coming years the number of patients will be about 300 million people [1-3]. One of the most important risk factors for heart disease in DM is chronic hyperglycemia, which causes cardiovascular disease and contributes to myocardial injury [4-8], and the degree of structural and functional changes in the components of the organ depends on various factors, including neurohumoral regulation $[9,10]$. It is known that in DM the renin-angiotensin system is activated, the antagonist of which is the atrial natriuretic peptide synthesized by atrial cardiomyocytes, in turn, this interaction affects the heart [11-15]. The pathomorphology of structural components of the organ in experimental hyperglycemia is described in details in the scientific literature $[16,17]$, but more attention has been paid to the structure of the myocardium, while ultrastructural changes of endocrine cardiomyocytes in the experimental hyperclycemia require more detailed study and in the future will predict the pathogenesis of heart disease in diabetes.

The aim of the study - to establish submicroscopic changes of atrial myoendocrine cardiomyocytes under the conditions of modeling of experimental hyperglycemia in rats of different age groups.

\section{MATERIALS AND METHODS}

An experimental study was performed on 24 outbreeding nonlinear adult male rats. The animals were kept in a vivarium under natural light and with free access to water and food. The research was performed in accordance with the international principles of the European Convention for the Protection of Vertebrate Animals Used for Experimental and Other Scientific Purposes (Strasbourg, 1986) and the General Ethical Principles for Animal Experiments (Kyiv, 2001). Manipulations with animals were performed under thiopental anesthesia. Animals were divided into two age groups: I - rats of pre-reproductive age (immature, 1.5-2 months, with a body weight of $90 \mathrm{~g} \pm 10$ g), II - rats of reproductive age (mature, 5-6 months, with a body weight of $190 \mathrm{~g} \pm 10 \mathrm{~d}$ ). Experimental hyperglycemia was simulated by a single intraperitoneal injection of streptozotocin (Sigma, USA). The injec- тання деструктивних явищ, вираження яких є вищою в групі щурів дорепродуктивного віку.

Ключові слова: серце; міокард; секреторні кардіоміоцити; субмікроскопічні зміни; гіперглікемія.

tion of the drug was preceded by a 12-hours animals starvation. Removal of animals from the experiment was carried out by decapitation on the 1st, 2nd and 3rd month of the experiment. Pieces of heart tissue were fixed in $2.5-3 \%$ solution of glutaraldehyde with phosphate buffer ( $\mathrm{pH}$ 7.2-7.4). Postfixation was performed with $1 \%$ osmium tetroxide solution, followed by dehydration in ethanol of increasing concentration and embedded into a mixture of epoxy resins. For electron microscopic studies, sections 0.4-0.6 $\mu \mathrm{m}$ thick made on an LKB-3 ultramicrotome were contrasted with uranyl acetate and lead citrate according to the Reynolds method. The sections were studied using an electron microscope PEM-125K at different magnifications $[18,19]$.

\section{RESULTS AND DISCUSSION}

Submicroscopic studies of the right and left atrial appendages of the studied groups of animals after one month of experimental persistent hyperglycemia showed changes in the structure of almost all organelles of endocrine cardiomyocytes. In the cytoplasm of cardiomyocytes of the atrial appendages, a large number of mature granules and granules in the stage of formation were noted, the main part of which had the form of membranous structures. A small number of nonmembranous forms of granules were observed, their clusters were located mainly in the perinuclear region of the cytoplasm. "Immature" granules were also found, they were located both around the nucleus and in groups between myofibrils, mitochondria and around hemocapillaries (Fig. 1).

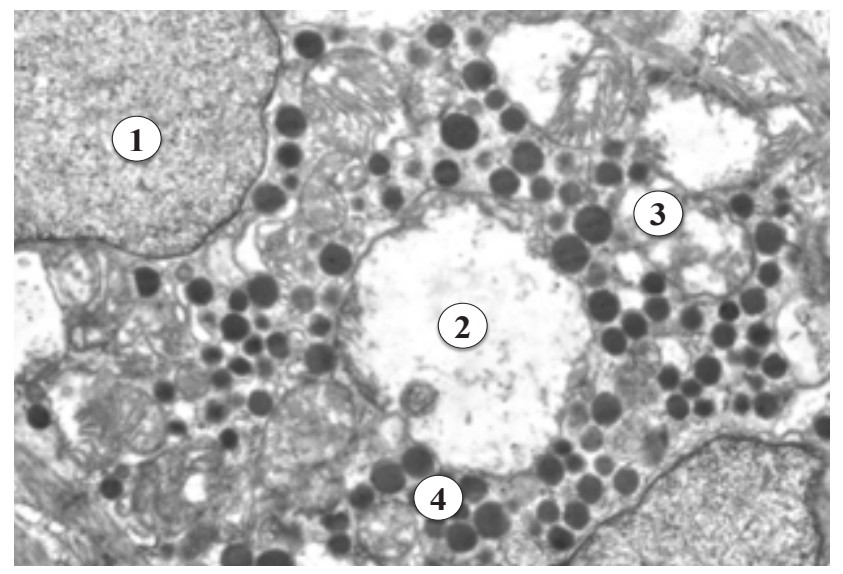

Fig. 1. Fragment of myoendocrine cell of the right atrial appendage of a rat of reproductive age after one month of experimental persistent hyperglycemia. Nucleus (1), vacuolated mitochondria (2), focal homogenization and enlightenment of the mitochondrial matrix (3), secretory granules (4). Electron micrograph. x21 000.
Вісник медичних і біологічних досліджень Bulletin of Medical and Biological Research
$4(10), 2021$ 
The karyoplasm of secretory cardiomyocytes of rats of both groups was electron-light, due to the predominance of euchromatin, it had one or two nucleoli. Some nuclei contained shallow invaginations, as a result of which the karyolema had a wavy contour. Mitochondria underwent significant changes, they were heteromorphic, densely packed, some of them were hypertrophied, swollen with an electron-enlightened matrix and damaged crystae (Fig.2). The contractile apparatus of endocrine cardiomyocytes was characterized by typical sarcomeres, the myofilaments of which maintained a parallel orientation. However, there were also myofibrils with sarcomeres of different lengths and disruption of myofilament ordering. Most cells had extended Z-lines (Fig. 3). In some cardiomyocytes there were changes of the contracture type, there were also areas of defibering of myofilaments and their lysis (Fig. 4). Most of cells contained sharply dilated tubules of the endoplasmic reticulum, elements of the

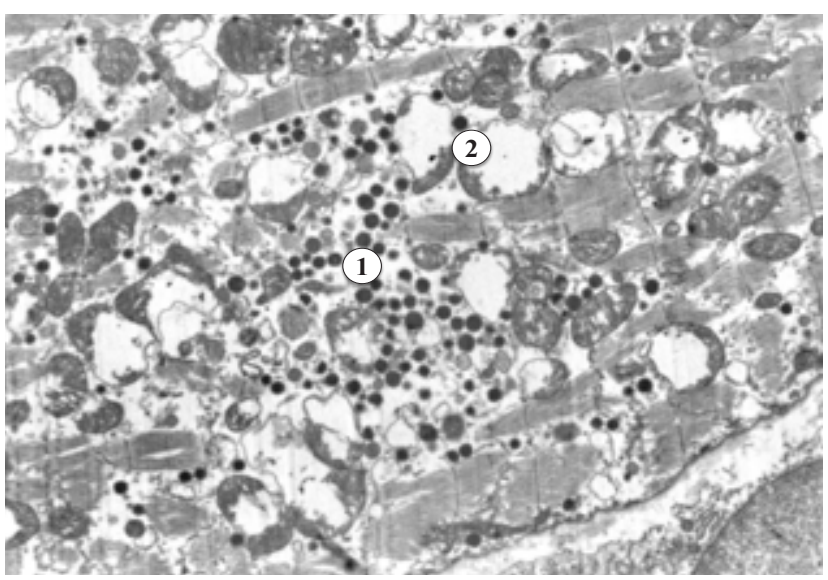

Fig. 2. Fragment of myoendocrine cell of the right atrial appendage of a pre-reproductive rat after one month of experimental persistent hyperglycemia. Diffuse arrangement of secretory granules (1), destruction of mitochondrial crystae (2). Electron micrograph. x17 000 .

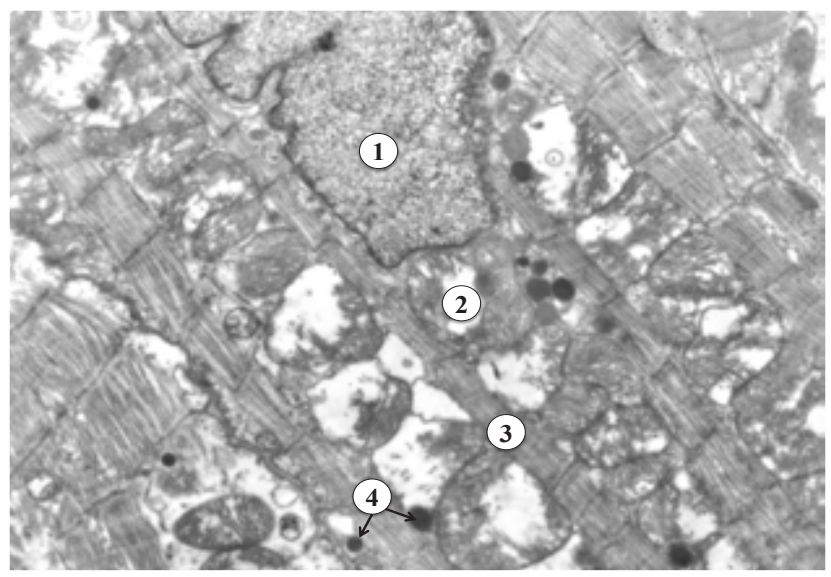

Fig. 3. Fragment of myoendocrine cells of the right atrial appendage of pre-reproductive rats after one month of experimental persistent hyperglycemia. Nucleus with invaginations of karyolemma (1), compact arrangement of mitochondria (2) between the strands of myofibrils (3), secretory granules (4). Electron micrograph. x18 000.
Golgi complex are hyperplastic. There was moderate intracellular edema, mainly in peripheral areas of cells. Due to edema, the intercellular lumens were increased, the structure of the intercalated discs was disrupted.

Submicroscopic changes of endocrine cardiomyocytes of the right and left atrial appendages after two months of experimental persistent hyperglycemia showed an increase in destructive changes in all cell organelles, which were more pronounced in the group of animals of pre-reproductive age. In animals of both age groups in the secretory apparatus of the cells of the atrial appendages was visually less granules compared to the previous study period (Fig. 5). "Immature" and nonmembranous forms of granules predominated, most of which contained osmiophilic, dense contents. There are a small number of mature granules, they did not form clusters but were evenly distributed in the cytoplasm. Topographically, the secretory granules were shifted to the subsarcolemmal

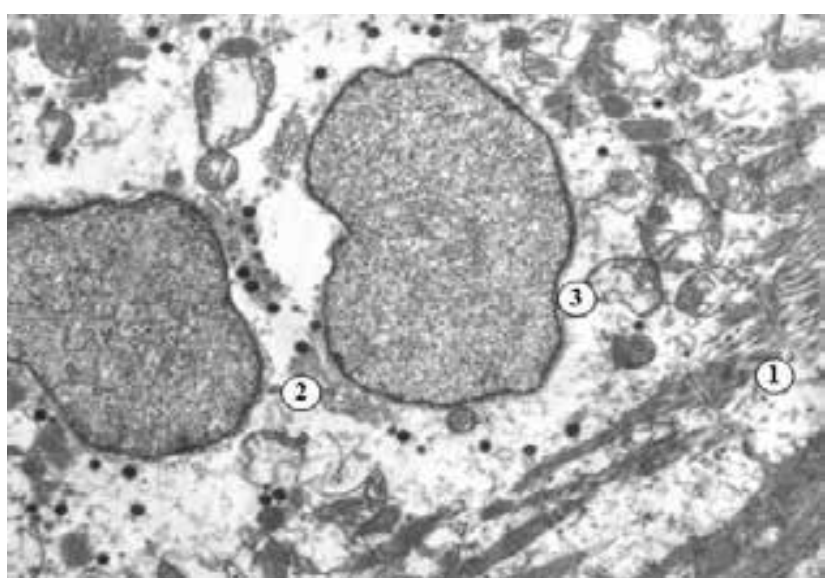

Fig. 4. Fragment of myoendocrine cells of the right atrial appendage of pre-reproductive rats after one month of experimental persistent hyperglycemia. Enlightenment of the cytoplasm due to lysis of myofilaments (1), hyperplasia of the Golgi complex (2), expansion of the perinuclear space (3). Electron micrograph. x.17 000.

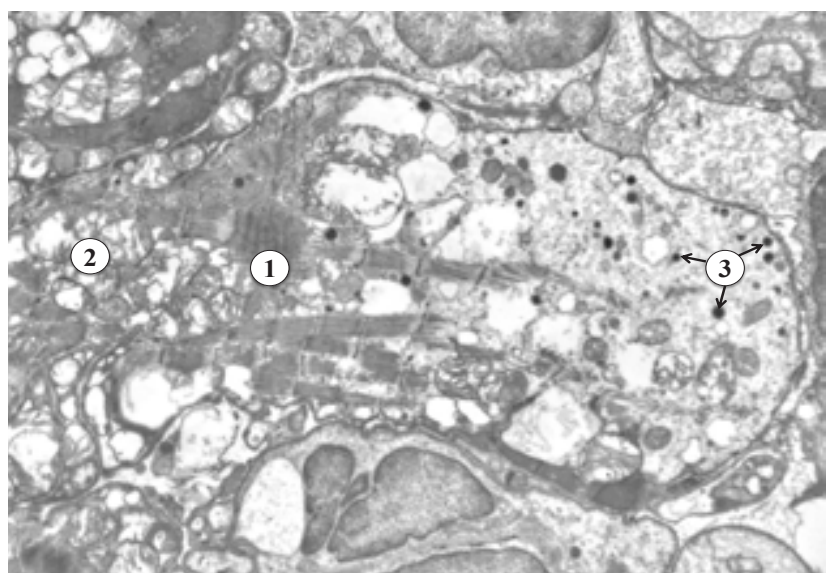

Fig. 5. Fragment of the myoendocrine cell of the right atrial appendage of a rat of reproductive age after two months of experimental persistent hyperglycemia. Abnormal intensive contraction of several sarcomeres of myofibrils (1), accumulation of mitochondria (2), secretory granules (3). Electron micrograph. x12 000. 
area in comparison with the previous term of the experiment. The nuclei of endocrine cardiomyocytes underwent significant ultrastructural changes. Thus, the karyolemma of the nuclei produced a significant number of invaginations, the karyoplasm was dominated by heterochromatin, which was located mainly in the areas under the karyolemma. Some nuclei have been pyknotically altered, with areas of karyolemma stratification, especially in cardiomyocytes changes with contracture type (Fig. 6).

Myofibrils were characterized by pronounced destructive changes, in particular, there were zones of myofibril overextension, areas of defibering, lysis and homogenization of myofilaments, Z-lines had a fragmented appearance due to splitting and displacement of myofibrils relative to each other. Sarcomeres in the area of the intercalated discs were destructively altered, poorly contoured (Fig. 7). Elements of the energy apparatus of cells were also with

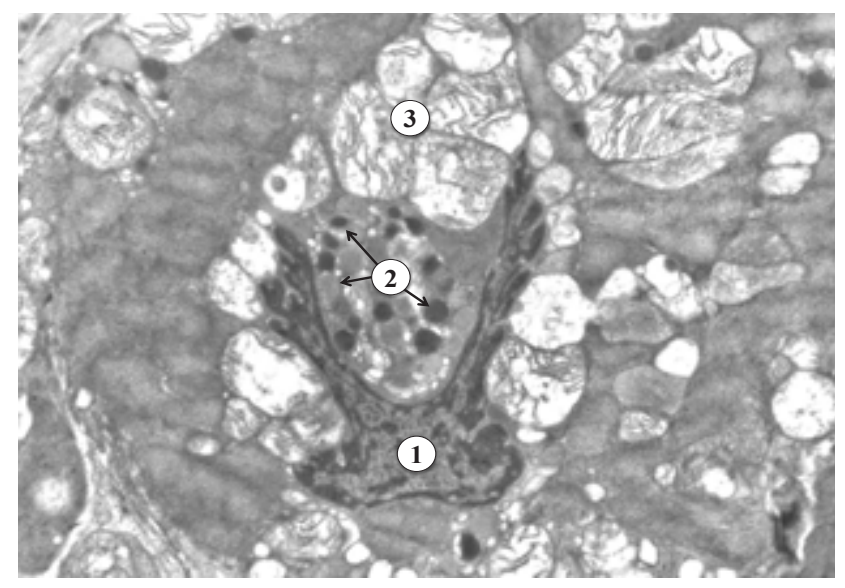

Fig. 6. Fragment of the myoendocrine cell of the right atrial appendage of pre-reproductive rats after two months of experimental persistent hyperglycemia. Pycnomorphic nucleus with a predominant content of heterochromatin in the karyoplasm (1) secretory granules (2), clusters of mitochondria (3). Electron micrograph. x15 000.

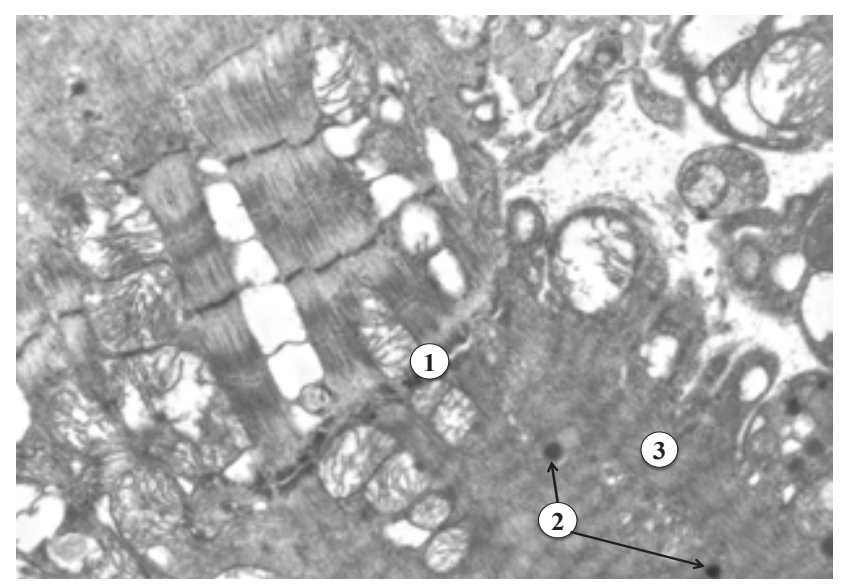

Fig. 7. Fragment of myoendocrine cell of the right atrial appendage of a pre-reproductive rat after two months of experimental persistent hyperglycemia. Intercalated disk (1), secretory granules (2), bands of myofibril with abnormal intensive contraction (3). Electron micrograph. x15 000. signs of pronounced destructive changes. Mitochondria were significantly swollen, with damage to the outer membrane, reduction of cristae, and an enlightened matrix. Mitochondria with electron-dense myelin-like inclusions were present between myofibrils (Fig. 8). The structural components of the Golgi complex, located both around the nucleus and under the sarcolemma, were hyperplastic. The tubules of the endoplasmic reticulum were dilated, sometimes fragmented.

The diffuse collagenization of the stroma was a typical sign of ultrastructural changes in the right and left atrial appendages after three months of experimental persistent hyperglycemia (Fig. 9). A large number of synthetically active fibroblasts with hypertrophied nuclei was observed, in which euchromatin predominated, and karyolemma formed numerous intussusception.

In the cytoplasm of secretory cardiomyocytes, mostly small granules were present, which were located irregularly in the swollen cytoplasm. Mature

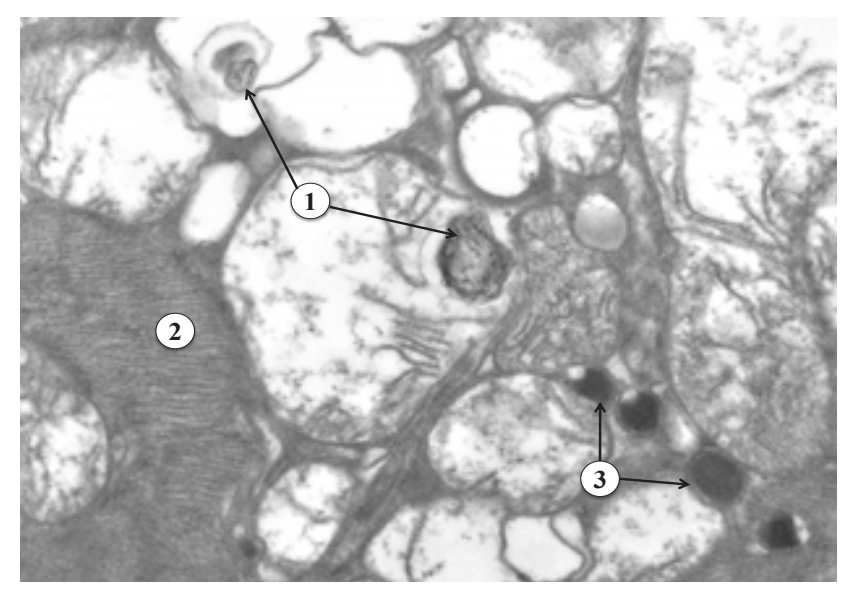

Fig. 8. Fragment of myoendocrine cell of the right atrial appendage of a pre-reproductive rat after two months of experimental persistent hyperglycemia. Myelin-like structures (1), myofibrils (2), secretory granules (3). Electron micrograph. x45 000.

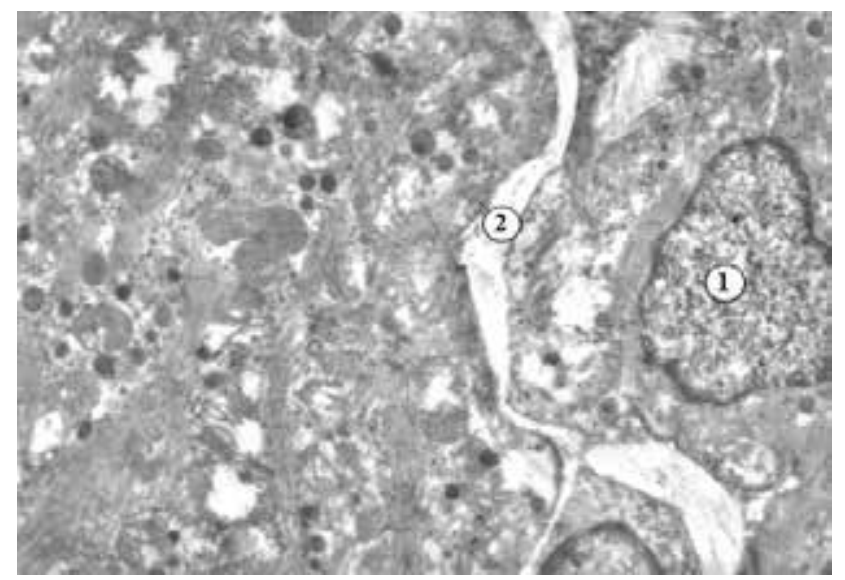

Fig. 9. Fragments of myoendocrine cells of the right atrial appendage of pre-reproductive rats after three months of experimental persistent hyperglycemia. Nucleus (1), layers of collagen fibers (2). Electron micrograph. x15 000 .
ISSN 2706-6282(print) ISSN 2706-6290(online)
$4(10), 2021$ 
forms of granules are more numerous in comparison with the content of such granules in the previous terms of research, and nonmembranous organelles were practically absent. During this period of the experiment, the increasing of destructive changes in the nuclei, contractile and energy apparatus of endocrine cardiomyocytes, as well as in the hemomicrocirculatory bed were also revealed. Endotheliocytes were in a state of significant edema, the number of organelles and micropinocytic vesicles was reduced, the basement membrane was thickened, damaged in some areas, the lumens of most hemocapillaries were narrowed. The nuclei of cardiomyocytes had significant enlightenment of the karyoplasm. Mitochondria were sharply swollen, there was a complete leaching of their matrix and the destruction of the outer membrane. Reduction and fragmentation of endoplasmic reticulum tubules were noted. In some cardiomyocytes, mitochondria, myofibrils, and other organelles were represented by heterogeneous mass without structural organization (Fig. 10).

\section{CONCLUSIONS}

1. At experimental persistent hyperglycemia in animals of different age groups stereotypical ultrastructural reorganization of contractile, nuclear and energy apparatus of secretory cardiomyocytes of myocardium of the right and left atrial appendages with development of compensatory-adaptive and destructive changes is noted. In the dynamics of the experiment there is an increase in destructive phenomena, the severity of which is higher in the group of rats of pre-reproductive age;

2. In hyperglycemia lasting one month in animals of both groups in myoendocrine cells there is an increase in the number of secretory granules mainly

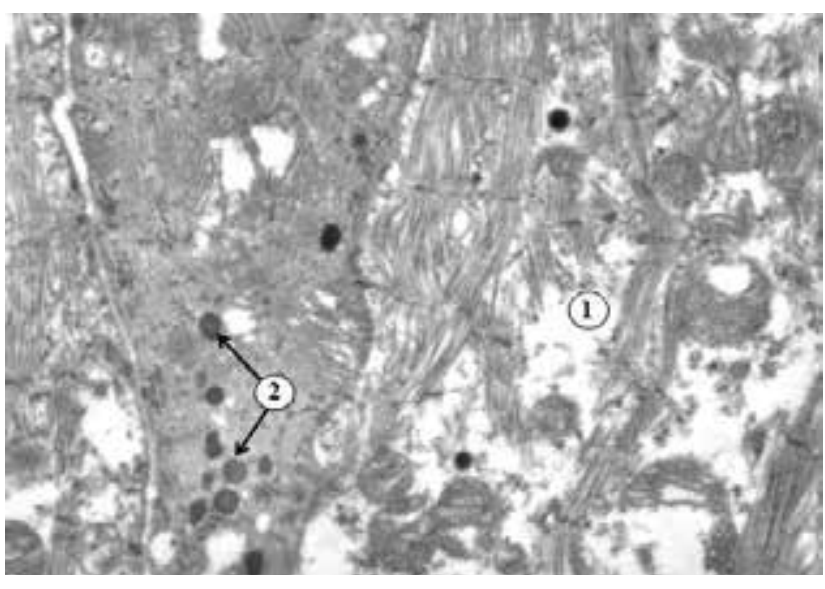

Fig. 10. Fragment of myoendocrine cell of the right atrial appendage of pre-reproductive rats after three months of experimental persistent hyperglycemia. Enlightenment of the cytoplasm due to lysis of myofibrils (1), secretory granules (2). Electron micrograph. x18 000

due to mature forms and granules in the stage of formation, indicating activation of synthesis and accumulation of atrial natriuretic peptide and inhibition of its excretion;

3. At two-month hyperglycemia, the reorganization of endocrine cardiomyocytes of the right and left atrial appendages of the heart is to reduce the total number of granules, the relative increase in granules in the stage of excretion, their diffuse location, indicating activation of atrial natriuretic peptide excretion from cells;

4. At three-month hyperglycemia, submicroscopic organization of the secretory apparatus of atrial appendages of the heart is characterized by chaotic location of smaller granules, reducing the number of nonmembranous forms, indicating disruption of compensation and inhibition of atrial natriuretic peptide from cells.

\section{LITERATURE}

1. Bain S. Multidisciplinary approach to management and care of patients with type 2 diabetes mellitus / S. Bain, M. Cummings, G. McKay // EMJ. Diabet. - 2019. - Vol. 7 (1). - P. 73-81.

2. Nathan D. M. The diabetes control and complications trial/epidemiology of diabetes interventions and complications study at 30 years: Overview / D. M. Nathan // Diabetes Care. 2014. - Vol. 37 (1). - P. 9-16. DOI: 10.2337/dc13-2112.

3. Бердник О. Г. Епідеміологія захворюваності на цукровий діабет 2 типу в Україні та світі : матеріали $\checkmark$ міжнар. наук.-практ. дистанц. конф. Менеджмент та маркетинг у складі сучасної економіки, науки. 2017 Берез 30-31 / О. Г. Бердник, Д. С. Орленко. - Харків, 2017. - C. 344-348.

4. Паньків В. І. Цукровий діабет: визначення, класифрікація, епідеміологія, фрактори ризику / В. І. Паньків // International Journal of Endocrinology. - 2013. - Vol. 7.55. - P. 95-104. DOI:10.22141/2224-0721.7.55.2013.84685.
5. Impact of diabetes on the predictive value of heart failure biomarkers / N. Alonso, J. Lupon, J. Barallat [et al.] // Cardiovascular Diabetology. - 2016. - Vol. 15 (1). - P. 151. DOI: 10.1186/s12933-016-0470-x.

6. Bertoluci M. Cardiovascular risk assessment in patients with diabetes / M. Bertoluci, V. Rocha // Diabetol. Metab. Syndr. - 2017. - Vol. 9. - P. 25. DOI: 10.1186/s13098-017-0225-1.

7. Thomas M. Type 2 diabetes and heart failure: Challenges and solutions / M. Thomas // Current Cardiology Reviews. - 2016. - Vol. 12. - P. 249 -255. DOI: 10.2174/1573 403X12666160606120254.

8. Сергієнко О. О. Діабетична кардіоміопатія: класифрікація, інструментальні методи діагностики / О. О. Сергієнко, В. О. Сергієнко // Mǐžnarodnij endokrinologìcnij žurnal. - 2020. -T. 16(7). - C. 577-587. DOI: 10.22141/2224-0721.16.7.2020.219012.

9. Association between insulin resistance, hyperglycemia, and coronary artery disease according to the presence 
of diabetes / Y. R. Cho, S. H. Ann, K. B. Won [et al.] // Scientific Reports. - 2019. - Vol. 9 (1). - P. 6129. DOI: 10.1038/ s41598-019-42700-1

10. Beverly J. K. Atherosclerosis: Pathophysiology of insulin resistance, hyperglycemia, hyperlipidemia, and inflammation / J. K. Beverly, M. J. Budoff // J. Diabetes. - 2020. - Vol. 12 (2). - P. 102-104. DOI: 10.1111/1753-0407.12970

11. Atrial natriuretic peptide and adiponectin interactions in man / A. L. Birkenfeld, M. Boschmann, S. Engeli [et al.] // PLoS One. - 2012. - Vol. 7 (8). - P. e43238. DOI: 10.1371/ journal.pone.0043238.

12. Brunner-La Rocca H. P. Natriuretic peptides in chronic heart failure / H. Brunner-La, P. Rocca, S. Sandersvan Wijk // Card. Fail Rev. - 2019. - Vol. 5 (1). - P. 44-49. DOI: $10.15420 / \mathrm{cfr} .2018 .26 .1$.

13. Coue M. Natriuretic peptide control of energy balance and glucose homeostasis / M. Coue, C. Moro // Biochimie. - 2016. - Vol. 124. -P. 84-91. DOI: 10.1016/j.biochi.2015.05.017.

14. Kerkelä R. Natriuretic peptides in the regulation of cardiovascular physiology and metabolic events / R. Kerkelä, J. Ulvila, J. Magga // J. Am. Heart Assoc. - 2015. - Vol. 4 (10). - P. e002423. DOI: 10.1161/JAHA.115.002423.

\section{REFERENCES}

1. Bain S, Cummings M, McKay G. Multidisciplinary approach to management and care of patients with type 2 diabetes mellitus. EMJ Diabet. 2019;7(1): 73-81.

2. Nathan DM. The diabetes control and complications trial/epidemiology of diabetes interventions and complications study at 30 years: Overview. Diabetes Care. 2014;37(1): 9-16. DOI: 10.2337/dc13-2112

3. Berdnyk OH, Orlenko DS. Epidemiology of type 2 diabetes mellitus in Ukraine and the world: materials of the $\mathrm{V}$ International. scientific-practical distance conf. Management and marketing as part of modern economics, science. Kharkiv. 2017. Ukrainian.

4. Pankiv VI. 2013. [Diabetes mellitus: definition, classification, epidemiology, risk factors]. International Journal of Endocrinology. 2013;7.55: 95-104. DOI:10.22141/2224-0721.7.55.2013.84685. Ukrainian.

5. Alonso N, Lupon J, Barallat J, de Antonio M, Domingo M, Zamora E. Impact of diabetes on the predictive value of heart failure biomarkers. Cardiovascular Diabetology. 2016;15(1): 151. DOI: 10.1186/s12933-016-0470-x

6. Bertoluci M, Rocha V. Cardiovascular risk assessment in patients with diabetes. Diabetol Metab Syndr. 2017;9: 25. DOI: 10.1186/s13098-017-0225-1.

7. Thomas M. Type 2 diabetes and heart failure: Challenges and solutions. Current Cardiology Reviews. 2016;12: 249-55. DOI: 10.2174/1573403X1266616060612 0254

8. Serhiienko OO, Serhiienko VO. $x$ Diabetic cardiomyopathy: classification, instrumental methods of diagnosis]. Miznarodnyi endokrinolohichnyi zhurnal. 2020;16(7): 577-87. DOI: 10.22141/22240721.16.7.2020.219012. Ukrainian.

9. Cho YR, Ann SH, Won KB, Park GM, Kim YG, Yang $\mathrm{DH}$, et al. (2019). Association between insulin resistance, hyperglycemia, and coronary artery disease according
15. Maisel A. S. Natriuretic peptides in heart failure: Atrial and B-type natriuretic peptides / A. S. Maisel, J. M. Duran, N. Wettersten // Heart Fail. Clin. - 2018. - Vol. 14 (1). P. 13-25. DOI: 10.1016/j.hfc.2017.08.002.

16. Heart failure and diabetes: metabolic alterations and therapeutic interventions: a state-of-the-art review from the Translational Research Committee of the Heart Failure Association-European Society of Cardiology / C. Maack, M. Lehrke, J. Backs [et al.] // Eur. Heart J. - 2018. - Vol. 39 (48). - P. 4243-4254. DOI: 10.1093/eurheartj/ehy596.

17. Qazi M. U. Diabetes and cardiovascular disease: Original insights from the Framingham heart study / M. U. Qazi, S. Malik // Glob. Heart. - 2013. - Vol. 8 (1). P. 43-48. DOI: 10.1016/j.gheart.2012.12.008.

18. Горальський Л. П., Хомич ВТ, Кононський ОІ. Основи гістологічної техніки і морфофрункціональні методи дослідження у нормі та при патології : навч. посіб. / Л. П. Горальський, В. Т. Хомич, О. І. Кононський. - Житомир : ЖНАЕУ, 2019. - 286 с.

19. Науково-практичні рекомендації з утримання лабораторних тварин та роботи з ними / Ю. М. Кожем'якін, О. С. Хромов, М. А. Філоненко, Г. А. Сайсретдінова. - К. : Інтерсервіс, 2017. 179 с.

to the presence of diabetes. Scientific reports. $2019 ; 9$ (1): 6129. DOI: 10.1038/s41598-019-42700-1

10. Beverly JK, Budoff MJ. Atherosclerosis: Pathophysiology of insulin resistance, hyperglycemia, hyperlipidemia, and inflammation. J Diabetes. 2020;12(2): 102-4. DOI: 10.1111/1753-0407.12970

11. Birkenfeld AL, Boschmann M, Engeli S, Moro C, Arafat AM, Luft FC, et al. Atrial natriuretic peptide and adiponectin interactions in man. PLoS One. 2012;7(8): e43238. DOI: 10.1371/journal.pone.0043238.

12. Brunner-La Rocca HP, Sanders-van Wijk S. Natriuretic peptides in chronic heart failure. Card Fail Rev. 2019;5(1): 44-9. DOI: 10.15420/cfr.2018.26.1.

13. Coue M, Moro C. Natriuretic peptide control of energy balance and glucose homeostasis. Biochimie. 2016;124: 84-91. DOI: 10.1016/j.biochi.2015.05.017.

14. Kerkelä R, Ulvila J, Magga J. Natriuretic peptides in the regulation of cardiovascular physiology and metabolic events. J Am Heart Assoc. 2015;4(10): e002423. DOI: 10.1161/JAHA.115.002423.

15. Maisel AS, Duran JM, Wettersten N. Natriuretic peptides in heart failure: Atrial and B-type natriuretic peptides. Heart Fail Clin. 2018;14(1): 13-25. DOI: 10.1016/j. hfc.2017.08.002.

16. Maack C, Lehrke M, Backs J, Heinzel FR, Hulot JS, Marx $\mathrm{N}$, et al. Heart failure and diabetes: metabolic alterations and therapeutic interventions: a state-of-the-art review from the Translational Research Committee of the Heart Failure Association-European Society of Cardiology. Eur Heart J. 2018;39(48): 4243-54. DOI: 10.1093/eurheartj/ ehy596.

17. Qazi MU, Malik S. Diabetes and cardiovascular disease: Original insights from the Framingham Heart Study. Glob Heart. 2013;8(1): 43-8. DOI: 10.1016/j. gheart.2012.12.008.

$4(10), 2021$ 
18. Horalskyi LP, Khomych VT, Kononskyi OI. Fundamentals ofhistological techniqueandmorphofunctional research methods in normal and pathology: textbook. [Основи гістологічної техніки і морфофрункціональні методи дослідження у нормі та при патології: навч. посіб.] Zhytomyr: ZhNAEU, 2019. Ukrainian.
19. Kozhemiakin YuM, Khromov OS, Filonenko MA, Saifetdinova HA. Scientific and practical recommendations for keeping laboratory animals and working with them. [Науково-практичні рекомендації 3 утримання лабораторних тварин та роботи з ними] Kyiv: Interservis; 2017. Ukrainian. 